\title{
CONTENDING DISCOURSES OF BLACK AUTOBIOGRAPHY: RESPECTABILITY, AUTHENTICITY, AND MASCULINITY
}

\author{
Anthony S. Foy ${ }^{1 *}$ \\ ${ }^{1}$ Swarthmore College, Swarthmore, PA, Unites States
}

\begin{abstract}
Summary
After historicizing the politics of racial representation in the slave narrative, this article considers how race, gender, and class intersect historically in the autobiographical production of Black men in the United States. At the dawn of the Jim Crow era, Black autobiography conformed to a cultural politics of racial synecdoche, which avowed that racial progress depended on the respectability of esteemed individuals. Dominated by aspirational figures who presented themselves as racial emblems, Black autobiography became closely aligned with the imperatives of Black middle-class formation, actuating a discrete form of racial publicity that erected disciplinary boundaries around Black self-presentation and silenced disreputable figures. With the emergence of criminal and sexual self-reference, whether subtle or striking, in the narratives of Black men, autobiographers like boxer Jack Johnson, scholar J. Saunders Redding, and writer Claude Brown, disrupted the class-bound constraints that had determined Black autobiographical production, staging an internecine class struggle over the terms of racial representation-that is, between contending discourses of racial respectability and racial authenticity.

Keywords: Black autobiography; racial uplift; crime; sexuality; phallocentric masculinity
\end{abstract}


For much of its history, African American autobiography has confronted the inescapable dilemma of racial publicity in the United States-that is, the dilemma of representing the Black self publicly, speaking to those racist constructions of Blackness that sanction material practices of anti-Black oppression while speaking for (and thus constituting discursively) a bounded racial collective. In the four decades prior to the U.S. Civil War, for example, the antebellum slave narrativethe firsthand account of bondage, resistance, and freedom by a fugitive or former slave, produced as a discrete text ${ }^{1}$-arose as a distinct form of Black testimony that fueled the transatlantic antislavery movement, confronting its readers with the unspeakable truths of racial slavery in the U.S. According to William L. Andrews (2019), 52 Black men and women published 61 such narratives between 1840 and 1865, but more than two-thirds of these were published after 1850 when the battle over slavery intensified with the passage of the Fugitive Slave Act (30, $328,248)$. Produced, promoted, and circulated to bolster the antislavery cause, the slave narrative captured the existential themes of American Romanticism and captivated antebellum readers. As documents of witness, these popular narratives protested the immoral deprivation and brutality of slavery while challenging the ideological premises of anti-Black thought. Demanding recognition of the enslaved person's humanity through ethical, religious, and sentimental appeals, these narratives also sought "to posit a full and sufficient self, as an act of selfcreation through the medium of language" (Gates 1992, 57). Since the 1980s, scholars' efforts to establish an African American literary canon have generally relied upon this equation between mastery of language and assertions of freedom, and for many scholars the antebellum slave narrative remains the canonical foundation for any account of African American autobiography, coalescing the heroic transhistorical principles of a cultural tradition that enacts Black freedom through language, attacks anti-Black ideologies, asserts Black humanity, and demands justice. At the same time, the antebellum slave narrative introduced another essential, if vexed, feature of Black autobiography that would continue to shape its historical trajectories-namely, the elevation of the exceptional, "freedom-bound individual whose goals and values contrast and occasionally conflict with those of his or her enslaved peers" (Andrews 2019, 254).

What, then, became of the slave narrative once slavery had been abolished in the U.S.? From the end of the Civil War to 1901, former slaves published 58 autobiographies, and they continued to publish their narratives well into the twentieth century (Andrews 2019, 318-19). ${ }^{2}$ Some of these testimonies continued to bear witness to the horrors of the past to counter the myth-making currents of plantation nostalgia, offering instead, as Louis Hughes (1969) writes in the 1897 preface to his Thirty Years a Slave, "accurate information regarding the character and influence of an institution which for two hundred years dominated the country" (3). By the end of the 1890s, however, the postbellum slave narrative began to emphasize pragmatism over protest, evincing the discourse of Black citizenship that quickly emerged after emancipation. As Saidiya Hartman (1997) argues, emancipation had promised the formal recognition of African 
Americans as rights-bearing citizens, but their transformed status required them to accept the prescriptions and pressures of liberal individualism, which actually authorized contractual mechanisms of subordination, like debt-peonage (119). Even as violence continued to subtend post-slavery practices of subjection, efforts to aid, educate, instruct, train, and manage freed people in the South effected a new discourse of Black citizenship. This discourse legitimated other practices of control that "fettered, restricted, and confined the subject precisely through the stipulation of will, reason, and consent" (Hartman 121); it also posited that Black people had incurred a debt to the nation with their emancipation. Black citizenship, then, did not ensure the recognition of natural rights so much as entail the demarcation of responsibilities, and postbellum slave narrators embraced these obligations with their tales of diligence and discipline, proving themselves worthy of their freedom. Accordingly, the distinct conventions of the postbellum slave narrative betrayed the contradictions of Black citizenship, refracted through "the burdened individuality of the responsible and encumbered freed person" who "enjoyed the obligations of freedom without its prerogatives" (Hartman 117, 132).

The freed people themselves actually challenged these contradictions, but the postbellum slave narrative did not focalize their counter-discourse of Black freedom (Hartman 132). By the late 1890s, the legalization of racial segregation launched the Jim Crow regime, marking the lethal reconsolidation of white supremacy in the U.S. In this grim context, postbellum slave narrators did not generally recount the despair of the fugitive or probe the power of slavery's afterlife to diminish Black freedom; instead, they extolled the virtues that had enabled freed people both to endure their enslavement with dignity and to capitalize on their freedom with determination (Andrews 1989, 69). While the antebellum slave narrative had featured individuals who had liberated themselves from the social death of slavery, the postbellum slave narrative featured individuals who had made themselves useful to new Black institutions, espousing "the adaptation of the individual to institutions as the hallmark of a successful life" (Andrews 1986, 22). Devoted to their churches and schools, these post-slavery autobiographers embraced their usefulness and self-denial in the interest of a larger racial cause. During its long development, then, the slave narrative shifted thematically from the defiant ideal of the unyoked, individual self to the practical vision of the sublimated, institutional self.

This shift coincided with a larger discursive shift within the Black public sphere as teachers, preachers, missionaries, leaders, businesspeople, and other professionals came to dominate Black autobiographical production by the end of the nineteenth century. This over-representation of aspirational figures meant that Black autobiography on the whole-not just the postbellum narratives of former slaves-was "avowedly, even proudly, middle-class in [its] values and aims in life," both reflecting and reproducing emergent discourses of "racial uplift" (Andrews 1986, 22). The ethos of racial uplift ostensibly promoted a broad vision of Black progress focused on solidarity, self-reliance, racial pride, and a common destiny (Mitchell 2004). However, Kevin K. Gaines (1996) has demonstrated that 
racial uplift actually encompassed a constellation of class-bound ideologies that shared "a limited, conditional claim to equality, citizenship, and human rights for African Americans" premised upon "the promotion of bourgeois morality, patriarchal authority, and a culture of self-improvement...as necessary to [the Black intelligentsia's] recognition, enfranchisement, and survival as a class" (Gaines 4, 3). The logic of racial uplift thus relied upon "a moral economy of class privilege, distinction, and even domination within the race, often drawing on patriarchal gender conventions as a sign of elite status and 'race progress"' (Gaines 17). Dominated by managerial figures with a common commitment to the values of racial uplift, the constellation of autobiographies published by African Americans after 1900 evinces a symbiosis between an aspirational Black leadership class and autobiographical production. Rooted in emergent ideologies of racial uplift, Black autobiography at the dawn of Jim Crow became a cultural mechanism of class formation, serving the interests of a Black middle class that sought to constitute itself discursively (though not exclusively) through narrative self-presentation. For the champions of racial uplift, autobiography established their representative authority on behalf of the race, based on their specific understanding of citizenship in terms of respectability and responsibility.

Racial uplift advanced an ideal of a unified, striving race rising towards a better future, but the aspirational figures who then dominated Black autobiographical production advocated differing political, social, cultural, and economic strategies to achieve Black progress. Despite these differences, their strategies of representation shared a commitment to a cultural politics of racial synecdoche-that is, racial uplift ideologies all emphasized the emblematic individual's responsibility for the status of the race according to a synecdochic relation wherein the part represents the whole, the constituent instantiates the community, the corporeal body stands for the collective body. Not all Black selves could earn recognition for all Black citizens, though. According to Gaines, crusaders for racial uplift assumed "a self-appointed personal duty to reform the character and manage the behavior of blacks themselves," and this managerial charge extended to racial representation as well (20). Because the Jim Crow regime depended upon anti-Black dogma to justify inequality, oppression, and extra-legal terror throughout the U.S., racial uplift ideologies held that the race's progress-material, political, economic, social, and cultural-entailed the public self-presentation of its most respectable members because "no people can hope to gain esteem and favor which fails to produce distinguished individuals illustrative and exemplary of its possibilities," as Kelly Miller (1968) argued in 1908 (200). Standing against an entrenched racist folklore that identified Black people with an essential assortment of both inadequacies (lack of intelligence, morality and self-control) and excesses (profligate sexuality and shameless criminality), the meritorious men and women who came to dominate Black autobiography consistently modeled bourgeois protocols of selfhood, presenting themselves as upright, lawful, chaste, modest, and self-disciplined. With this political investment in the symbolic power of emblematic individuals, racial 
uplift ideologues adapted Black autobiography to their common representational imperative, especially because the defining referentiality of autobiography bolstered its ability to counter racial "science," stereotype, and myth with the truths of a race on the rise.

Aligned with the interests of a discrete class, African American autobiography became a crucial site of Black middle-class formation that predicated representative authority on manifest respectability, while the status of the book-form itself, beyond the vaunted demonstration of literacy, presumably accrued cultural capital to published Black authors. According to this bourgeois anti-racism, "Black elites who spoke of uplift opposed racism by calling attention to class distinctions among African Americans as a sign of evolutionary race progress" (Gaines 20). Consequently, Black autobiographers of the Jim Crow era often defined themselves against the unrestrained Black (and mostly workingclass) people they presumed to manage. For example, the most influential of postbellum slave narratives, Booker T. Washington's Up from Slavery, published in 1901, describes the rough dances, hard drinking, and gun play that typified the rural districts of Alabama before the salutary influence of his Tuskegee Institute; it also depicts the criminal potential of wayward Black people who, Washington suggests, resort to theft and prostitution when their desires to consume outgrow their abilities to produce (Washington 1996, 63-64, 21). For Washington, the reckless behavior and irresponsible consumption of the Black folk ultimately conjure the prison, whereas his school trains Black bodies to labor productively, leading them away from the prison's shadow. Drawing this stark opposition between the disreputable and the decent, Up from Slavery summons the excesses of other Black people as Washington narrates his own sober rise from slavery, which then authorizes his standing as a respectable, responsible, and restrained Black leader. The apparent commitment to self-discipline among Jim Crow-era autobiographers like Washington, rendered in contrast to the Black masses, meant that autobiography crystallized as a disciplinary mechanism during this period. As the quintessential form of literary self-presentation, autobiography allowed individuals to exemplify the capacity of Black elites for self-discipline through their compelling personal stories. If, as Eagleton (1991) observes, "[b] ourgeois ideology...is the form of dominative discourse which would present itself as entirely innocent of power" (154), then Black autobiography's discursive commitment to racial uplift also delimited self-serving boundaries around the range of possibilities for racial self-presentation, thereby disciplining the proper Black subject of autobiography while seeming innocent of intraracial power. These firm disciplinary boundaries would thus stifle Black autobiographical subjects, restricting who could embody the race, what could authorize them to represent the race, and how they could narrate the past, the progress, and the promise of the race through their own emblematic tales.

Until the 1960s, this disciplinary class logic of racial representation would effectively privilege respectable Black figures while excluding, if not disavowing, others it deemed disreputable. Just as a broad view of Black autobiography 
exposes the ideological pressures that overdetermined the form, attention to both neglected and noted texts reveals how indecorous forms of sexual and criminal self-disclosure eventually emerged to contest the dominance of racial uplift. Whereas earlier writers delineated their own propriety by depicting, if warily, the sexuality, criminality, and recklessness of other Black people, these new autobiographical figures troubled the upright boundaries of Black autobiography by drawing such subjects into the orbit of the narrated Black self. In particular, Black male autobiographers like Horace Cayton, Malcolm X, and Claude Brown cleared new narrative space for illicit Black subjects: they disturbed the synecdochic logic of racial publicity that had disciplined the form; they eroded the class-bound ideologies that had constrained them; they contested the established aims, bases, and constituencies of Black autobiography; and, most importantly, they often linked such self-revelation to their critiques of Black elites. One of the untold stories of twentieth-century Black autobiography involves this internecine clash over the terms of racial representation itself as disreputable Black figures became disruptive.

In the context of this history, the autobiography of famed boxer Jack Johnson (1992) offers a poignant nodal point in the trajectories of Black autobiographical production. Published in 1927, Jack Johnson-In the Ring-and Out is a fanciful act of self-fashioning, a colorful account of the heavyweight boxer's rise to fame that details many of his professional bouts, some of his private loves, his entanglements with the law, his adventures as a fugitive champion, and his imprisonment in the U.S. Flamboyant and immodest, Johnson had faced racially motivated criminalization during his boxing career, largely for his sexual affairs with white women. Wrangling self-consciously with his public image, Johnson illustrates how the disreputable Black figure adapts his life to the demands of racial publicity, recognizing that "it was my own honor, and in a degree the honor of my race" implicated in his symbolic status as the first Black heavyweight champion (183). While In the Ring - and Out emphasizes Johnson's refinement, it also heralds the autobiographical figures who would eventually disrupt the discreet silences upon which uplift autobiography had insisted. With references to their own sexuality and accounts of criminality, criminalization, and imprisonment, these figures attested to the shifting discursive ground upon which a Black man could claim to speak for the race authoritatively and authentically. Johnson's transitional autobiography thus illuminates the intraracial struggle over representation that would alternately constrain and compel the trajectories of Black autobiography in the twentieth century.

\section{Sexual Subjects}

Jack Johnson still embodied a renegade Black masculinity when In the Ring-and Out appeared in 1927. As heavyweight champion from 1908 to 1915, Johnson had faced a relentless campaign to suppress his image and police his sexuality, culminating in two federal laws inspired by his visibility as a Black 
boxer and celebrity. He had been a dominating fighter in the ring who teased and taunted his white opponents mercilessly, and his mastery of white men in the boxing ring was such an affront to global white supremacy that efforts to ban films of his fights began in 1910 as "a national campaign that quickly evolved into a transnational crusade" (Runstedtler 2012, 78-79). To suppress all films of Johnson's fights, the U.S. Congress passed the Sims Act in 1912, a federal law that banned the distribution of fight films altogether (Runstedtler 79; Grieveson 2004, 130-33). Meanwhile, contemporary anxieties in the U.S. over "white slavery," Black male sexuality, and miscegenation meant that efforts to contain Johnson's image were also "influenced by a desire to prevent the display of a desirable black male body from erotic contemplation" (Grieveson 142). At a time when Black men were routinely lynched for far less, Johnson's conspicuous escapades with white women provoked the wrath of the federal government. In 1913, he was convicted of violating the Mann Act of 1910 (also known as the "White Slave Traffic Act"), which banned the interstate transportation of (white) women "for the purpose of prostitution or debauchery, or for any other immoral purposes" (qtd. in Ward 2004, 298). Criminalized for publicly wooing and wedding white women, Johnson spent seven years abroad as a fugitive before returning to the U.S. to serve his sentence at Leavenworth Penitentiary from 1920 to 1921. In the wake of this state-sanctioned persecution, Johnson's autobiography would embrace the trappings of respectability to recover his body from the scrutiny of a hostile public.

According to Johnson's genteel self-fashioning in In the Ring-and Out, he is more of a businessman than a bruiser, more of a cosmopolitan than a fugitive, more of a patriot than a peril; against his image as a sexual outlaw, Johnson also narrates himself as more of a faithful partner than a philandering playboy. Nonetheless, his autobiography betrays a struggle between decent and disreputable models of Black masculinity. Abiding by the Victorian strictures of racial uplift, earlier Black male autobiographers had carefully avoided any hint of their own sexuality, of which children were its only conceivable signs. Black male sexuality thus appeared obliquely in their narratives as a strict matter of procreation, not pleasure (Moses 1990; Tate 1992, 166-68; Gaines 78-79). This consistent emphasis on a patriarchal ideal in Jim Crow autobiography effectively stifled dangerous alternatives that rooted Black masculinity in the virility of a carnal body. Analyzing twentieth-century shifts in forms of male dominance among Black men, bell hooks (1992) observes that:

$[W]$ ith the emergence of a fierce phallocentrism, a man was no longer a man because he provided care for his family, he was a man simply because he had a penis. Furthermore, his ability to use that penis in the arena of sexual conquest could bring him as much status as being a wage earner and provider. A sexually defined masculine ideal rooted in physical domination and sexual possession of women could be accessible to all men (94). 
Throughout his boxing career, Johnson himself cultivated a reputation for sexual prowess, often manipulating the tense contrast between phallocentric masculinity and patriarchal respectability: on the one hand, he called attention to himself "as an embodiment of highly sexed [Black] masculinity" by wrapping his penis before public sparring exhibitions, magnifying it as both shadowy threat and seductive fetish (Bederman 1995, 10; Gilmore 1975, 14); on the other, he routinely invoked coverture by referring to his white female companions publicly as "Mrs. Johnson" regardless of their official legal status, insisting that they be treated "as wealthy, respectable women whose husband was successful and manly enough to support them in comfort and luxury" (Roberts 1983, 9; Bederman 9). Likewise, Johnson introduces phallocentric masculinity to Black autobiography under the cover of patriarchal respectability.

In the Ring-and Out employs a discourse of romance and matrimony to euphemize Johnson's sexuality, and this appeal to bourgeois decorum obscures his sexual self-disclosure. Still, Johnson's palimpsestic narrative retains the traces of his sexual aura, the inescapable keystone in the arch of his notoriety. His autobiographical references to his romantic relationships offer winking allusions to his virility, and the prominence of white women in his book conjure the phallocentric Black masculinity that made him both fearsome and fascinating. For example, In the Ring-and Out includes photographic portraits of two of his three white wives, and one of these portraits accompanies "My Husband," a defensive preface by "Mrs. Jack Johnson," his fourth wife (Johnson 16-20); along with the autobiography's other images of Johnson's semi-clad body in boxing poses, these illustrations draw the racial politics of Johnson's public bouts into personal, intimate spaces. Johnson also includes an unusual fifth chapter, "Romances and Regrets," which he devotes to his love affairs both within and outside of marriage. Opening with a brash declaration- "There have been countless women in my life" (Johnson 70)-this chapter recounts a series of relationships with Black and white women before describing Johnson's arrest for violating the Mann Act and his flight as a fugitive. Indeed, Johnson's account of the arrest itself encapsulates the narrative's play of respectability and virility. Storming Johnson's train to apprehend him, federal agents order the boxer to open his stateroom door, but "I told them that they could not come in-that Mrs. Johnson and I were not dressed.... They waited, however, and donning our clothes we went out to meet them" (Johnson 84). Invoking decency and decorum to protect "Mrs. Johnson," his white wife, the boxer keeps the authorities at bay; for readers, however, Johnson evokes the interracial intimacy of these two naked bodies, despite his ostensible performance of respectability. Resonating with his public performances as Black champion, his autobiography manipulates racialized codes of masculinity to launch a phallocentric politics of fulfillment staked on the bodies of white women. The State's repressive response to his conspicuous affairs thus compounds the meaning of Johnson's white lovers as tokens of his virility, autobiographical signs of his unmanaged sexuality. While In the Ring-and Out might seem to repress the phallocentric dimensions of Johnson's masculinity 
according to the dictates of patriarchal respectability, even within these limits his sexuality surfaces in his narrative through the tense signifying dialectic between his sexual reputation and his refined self-presentation.

J. Saunders Redding's No Day of Triumph (1942) is another key transitional narrative in this development, culminating in a significant, if subtle, moment of sexual self-reference. In time, this prolific Black scholar would become better known for his conservative tendencies, but Redding's earlier travel narrative takes aim at the rigid insularity of the Black middle class, a "vivid" indictment that promised, according to Richard Wright's terse introduction, to "rock the Negro middle class back on its heels" (Redding [2]). After devoting the first of his four chapters to his own upbringing in the North, Redding retraces his 1940 road trip through the South searching for the meaning of Blackness, immersed primarily among the Black folk left behind by the tides of northern migration. No Day of Triumph concludes with a Louis Armstrong show in rural Louisiana, and in the local dance hall-segregated in theory, but integrated in practiceRedding discovers a utopian space of earthly freedom. With the introduction of Menola Melancon, the local waitress he invites to the show, he also infuses his narrative with his own desire. After his initial description sexualizes herhe comments that "[h]er breasts stood up aggressively, and in her gait there was a certain casual frankness," for example (331) - Redding envelops his brief encounter with Melancon in a mist of Creole exoticism. Outside the dance hall, "the whole scene seemed strangely foreign and exciting," while inside, Melancon's "big, vital body weaved a fluid pattern before me. She swayed in the unmistakable vestige of a symbolic dance remembered by her blood"-a medley of "the Cajun, Indian, Negro, White" (335, 338). Melancon dances "with absolute freedom," and, Redding writes, "I saw her everywhere, like an embodied essence" (339). Amid "[t]he warm odors, at once sweet and yeasty" of the animated Black and white bodies filling the dance hall, "I gave myself up to the dance," he admits $(337,338)$.

This experience with Melancon inspires Redding's final meditation on the meaning of freedom, but this epiphanic climax depends on his own embodiment. Evoking his own carnality, he construes the exotic woman's dancing body as a sign of sexual abandon; conflating sexual liberty and racial freedom, he renders the narrative's conclusions about Black salvation in masculinist terms. Ultimately, No Day of Triumph weds Redding's critique of the Black middle class to a putatively anti-bourgeois sensuality, equating his symbolic quest for the meaning of Black lives with the recovery of authentic Black masculinity through the desirous body. With the eroticization of this quest, Redding resorts to a banal trope by depicting the Black folk-and, in the end, Black women - as the site of natural, unfettered sexuality. ${ }^{3}$ Still, Redding draws attention to himself, suggesting his own sexuality at his narrative's dénouement as the sensual physicality of the dance hall arouses in him a "gendered self-consciousness" that he mystifies as merely racial consciousness (Carby 1998, 37). In this nuanced way, Redding challenges the sexual silence of earlier Black male autobiographers, even if his phallocentric imagination stops short of an explicitly rendered sexual conquest. 
By the mid-1960s, the once-hegemonic mode of uplift autobiography had begun to splinter from the force of new challenges, and the narratives of Johnson and Redding would prefigure later disruptive forms of phallocentric narrative. In 1965 alone, at least three significant autobiographies first published that year evinced Black men's sexual self-consciousness. In Long Old Road (1965), Horace R. Cayton explores the psychological vulnerability of Black men in a racist society while exposing the psychic costs of becoming a Race Man; probing the politics of interracial desire, Cayton's narrative investment in manhood relies heavily on accounts of his sexual affairs with white women. Structured as a conversion narrative, The Autobiography of Malcolm X (1973) offers an analysis of the sexual politics of race from the perspective of a street hustler, and Malcolm X's own affair with a young white woman conveys the "sense of masculine authority and power" he gains from his own sexuality (Marable 2011, 46). Claude Brown's Manchild in the Promised Land (1965), a meandering tale of his coming of age in Harlem, describes how sexual conquests inform his streetwise masculinity. Later, Beneath the Underdog (1971) would relate a ribald, surreal life story alternating between Charles Mingus's musical ascent and his sexual exploits. Notably, the pimp, as "an idealized representation of racialized masculinity" (RustinPaschal 2017, 43), figures significantly in the narratives of Malcolm X, Brown, and Mingus, and the ultimate autobiographical expressions of an exploitative phallocentric masculinity-that is, of sexual mastery and control over womenare undoubtedly Pimp (1969) and The Naked Soul of Iceberg Slim (1971), two autobiographical texts written by erstwhile hustler Iceberg Slim (the nom de plume of Robert Beck).

Such self-disclosure coincides with broader historical currents, including the tides of sexual liberalism that increased after the Jazz Age and blossomed during the 1960s into a "sexual revolution" beckoning the Black man as both actor and fetish (Medovoi 1999; D’Emilio and Freedman 1988; Allyn 2000). Moreover, "discourses about [Black] male sexuality became central to consolidating nationalist identities" as the Black Power movement gained prominence in the 1960s (Murray 2007, 11). Nonetheless, sexual self-disclosure among these later autobiographers (not all of whom could be neatly characterized as nationalists) cannot be dismissed as a mere effect of historical tendencies because they mobilized phallocentric masculinity to defy the intraracial politics of respectability that had overdetermined Black autobiographical production. While anxious practitioners of uplift autobiography had been resolute in conveying the high-minded selfcontrol of decorous patriarchs, these later autobiographers rendered the phallocentric imperatives of their own sexual deeds and desires to reconstruct an "authentic," anti-bourgeois version of Black masculinity. Such expressions of phallocentric masculinity signal the discourse of racial authenticity that arose to contest the older, dominant discourse of racial respectability. Likewise, Black narratives of criminality - which, by the 1960s, often intersected with their subjects' sexual self-reference-would also disrupt the class-bound dictates of racial publicity. 


\section{Criminal Subjects}

In general, crime tales-both criminal and convict narratives-were commonplace in the U.S. by the end of the nineteenth century and were exceedingly popular by the 1930s (Franklin 1989). However, because of the distinct alignment of Black autobiography and middle-class formation, published African American narratives of criminal self-disclosure were virtually absent for a century after emancipation. According to prevalent discourses of racial uplift, the operative distinction between the depiction of crime (by others) and its admission (by oneself) was pivotal: admitting to dubious past acts would suggest that criminality is somehow constitutive of both the narrated and narrating Black subject, undermining the cultural politics of racial synecdoche that drove Black autobiographical production during the early Jim Crow era. Distilling the anxieties of a Black middle class, discourses of racial uplift starkly distinguished upright figures from criminal figures in the popular imagination at a time when social scientists had begun to produce a new "racial knowledge" in the 1890s through demographic statistics, positing "black criminality... as a fundamental measure of black inferiority" (Muhammad 2010, 20). In 1904, for example, Booker T. Washington insisted that the sharp boundaries between decent and indecent Black people must be maintained in order to satisfy moral qualifications for recognition and to ameliorate the image of the African American middle class:

Some people assert that no matter how rich and educated we become, we lack morality, we accept as equals people who have been in jail and penitentiaries. But we must see to it that we are as rigid in our standards as anybody else. We must drive out from among us immoral people, whether teachers, preachers, or laborers (qtd. in Lamont 1904, 7-8).

Of all of the Black autobiographies published in the seven decades following Reconstruction, just eight present their subjects as figures of crime. Racial uplift ideologies promoted the character of emblematic Black figures in order to substantiate the race's respectability, so the imputation of crime alone could tarnish one's authority to represent African Americans publicly. By "figures of crime," then, I refer to any autobiography wherein this discursive specter of the Black criminal haunts the subject's self-presentation. Along with more frank crime tales and prison narratives, this capacious category includes texts in which narrated Black subjects must establish their innocence by addressing a blighted public reputation. Between 1877 and 1950, the small group of Black autobiographies by figures of crime mostly involve narratives of criminalization rather than narratives of criminality-that is, they involve Black narrators who do not write primarily as criminals but whose public reputations depend in some degree on criminal allegations against them, as well as those who have been unjustly jailed. These autobiographers use their narratives, whether in whole or in part, to defend themselves against either local or national notoriety. For example, L.R. Ferebee's postbellum slave narrative (1882) is the first post-Reconstruction 
autobiography to discuss its author's imprisonment, which the narrative blames on the machinations of his political rivals. J. Vance Lewis's Out of the Ditch (1910), describes his early life under slavery and his eventual rise to become a prosperous lawyer in Houston, but it also addresses his persecution by conspiratorial rivals, both Black and white, who were responsible for two different indictments against him for fraud and forgery. Lewis ultimately prevails, and in his concluding chapter he reclaims his respectability, asserting in terse, masculinist terms his devotion to his faithful wife, his cultured home, and his "considerable property" (Lewis 153-54). In later years, other narratives of criminalization grew out of two famous trials of the 1930s, which exposed the ambivalence of middle-class Black leaders who sought to protect the race's image against disgraceful accusations: published in 1937, Let Me Live (2007), the autobiography of Communist organizer Angelo Herndon, politically persecuted and convicted of insurrection under a Reconstruction-era law in Georgia; and Scottsboro Boy (1950), the autobiography of Haywood Patterson, one of nine Black youths falsely accused of raping two white women in Alabama in 1931.

Because Jack Johnson's ostentatious challenges to white supremacy included an assertion of phallocentric Black masculinity that sparked his persecution, In the Ring - and Out amounts to a narrative of criminalization that must address the risky tinder of race, gender, sexuality, and power. Johnson first tests the classbound constraints on Black autobiography by describing his early arrests for gambling, vagrancy, and even prizefighting itself (interracial bouts prompted the enactment and enforcement of local anti-boxing ordinances in the U.S. throughout his career). More importantly, though, Johnson uses his autobiography to address the criminalization of his sexuality under the Mann Act. Contending with Johnson as a figure of crime, his narrative thus departs from earlier uplift autobiographies in two key ways: first, his self-referential accounts of gambling, itinerancy, and fighting incorporate some of the unwholesome signs associated with Black working-class culture that devotees of racial uplift attempted to police with their own respectable self-presentations; second, his narrative eschews discretion to confront the criminalized intersection of sexuality, Black masculinity, and white supremacy. Despite his relative candor, Johnson nonetheless presents himself as a self-made man of bourgeois taste, refinement, and sensibility. Even in prison, he occupies a managerial role as the "physical director" with "many duties and obligations," continues to look after his "personal and business affairs outside the prison," and he describes an exhibition bout there as "fast and classy" (Johnson 129, 132). In the Ring-and Out insists that it wields Johnson's true character against a false reputation, defending him against his criminalization as a sexual outlaw. However, his recourse to respectability cannot quite dull the sharp edges of infamy that offended the conventions of uplift autobiography.

Even rarer in the period from Reconstruction to 1950 are published narratives of criminality in which Black autobiographers admit their own disreputable pasts and in which most (though not all) of these autobiographers derive their primary authority from their experiences as criminals and, more often, as convicts. Only 
two such narratives exist: Buried Alive (Behind Prison Walls) for a Quarter of a Century (1892), the as-told-to narrative of William Walker published by Thomas S. Gaines; and Bootlegging a Failure and a Lecture to Young Men (1918), the selfpublished prison narrative of Ide Nash. Walker's Buried Alive diverges from the pragmatic conventions of other postbellum slave narratives, and it singularly captures the violent continuities between the antebellum plantation and the postbellum prison. With the help of Gaines, another Black male convict released from prison in 1892 with manuscript in hand, the illiterate Walker recounts in the first third of Buried Alive his life under slavery in Virginia, Louisiana, and Missouri, his escape to Canada on the eve of the Civil War, and his life as a laborer just outside of Detroit in the early 1860s. In 1866, however, Walker is convicted of murder after killing his white neighbor in an act of self-defense, entering Michigan State Prison, "my rock-bound grave," on Christmas Day (Gaines 66). The final two-thirds of Buried Alive details Walker's experiences as a "lifer" in the penitentiary. While Buried Alive concludes with a perfunctory comment on the importance of education and Christianity in rehabilitating prisoners, Walker's narrative is not structured as a confession of crime followed by a public declaration of repentance. Rather than mold his life to fit the conventions of uplift autobiography, Walker stands as a witness to the brutal inhumanity of penal practices, denouncing in particular the Northern system of convict labor, an exploitative public-private partnership that he decries as "a worse system of slavery than ever existed on Southern soil" (Gaines 74). With its critique of the historical continuum of anti-Black institutions, Buried Alive extends the political imperatives of the antebellum slave narrative but disrupts its typical teleology of freedom. It is also the rare postbellum slave narrative that offers political critique without the overdetermined performance of respectability.

In contrast, Nash's Bootlegging confirms rather than counters the discourses of racial uplift that had become so dominant in the Black public sphere since the 1890s. Self-published more than twenty-five years after Walker's Buried Alive, Bootlegging offers a confessional narrative of Nash's experiences in and out of jail in Texas, the Indian Territory, and Oklahoma before describing his most recent two-year stint in the Oklahoma State Prison for bootlegging whiskey. Endorsing the uplift ideology of Booker T. Washington, Nash molds his life into a cautionary tale for others, particularly young Black men. As the repentant Nash puts it, "My advice, boys, is to stay out of the penitentiary, and remember always, that a dime's worth of freedom is equal to dollars in prison" (64). Nash appends to his narrative a number of other texts, such as the titular "lecture to young men," an essay addressed to the "colored boys throughout the country," and an etiquette list, which admonishes Black youth, "Do not praise Jack Johnson and condemn Booker T. Washington" and "Do not forget that the best class of people are always your friends” $(88,89)$. Although Nash's account suggests that he had resorted to bootlegging repeatedly, against the advice of his friends, because of the insecure life of a Black farmer, Bootlegging does not offer a critique of structural conditions. Like Washington, Nash argues instead that Black people 
should forsake the city for the country, learn scientific agriculture to work the land more efficiently, and shun political protest. Moreover, Nash's representation of prison replicates the class distinctions characterizing racial uplift ideologies. He laments that "it was a great punishment to one who had gentlemanly morals to be in with such unmanly brutes," and throughout his narrative he stresses how his own education, patriotism, and Christian piety distinguish him from many of the other convicts, especially his fellow Black inmates (27). Whereas Buried Alive presents Walker as a representative speaking on behalf of his fellow prisoners, Bootlegging naturalizes class distinctions within the prison in order to isolate Nash from the "bad men... who are anxious to get their freedom, so they can violate the laws again" (Nash 38). With Bootlegging, Nash attempts to situate himself within discourses of racial uplift despite his criminal credentials.

After 1950, autobiographical Black subjects began to appear as figures of crime with greater frequency. Whereas only eight such autobiographies appeared between 1877 and 1950, nine more were published from 1951 to 1965, and thirty-five more appeared from 1966 through the 1970s. This gradual upsurge after 1950 consisted almost entirely of narratives of criminality, though some molded their narrators' lives into stories of personal reform, like Nash's Bootlegging. In 1951, Matt Thomas published Hopping the Border: The Life Story of a Bellboy, a good-natured chronicle of Thomas's working life and business ventures, including such "mischief" as bootlegging and bookmaking (167). Thomas A. Jones's The Secret (1958) unapologetically details a Black gambler's career in Washington D.C.'s underworld. Heavyweight boxers Archie Moore (1960) and Floyd Patterson (1962) both published autobiographies in the early 1960s that describe how prizefighting allowed them to make something of themselves, despite youths marked by delinquency and crime (the disciplinary import of Patterson's narrative is embedded in its title, Victory Over Myself). For these two Black athletes, their confessions of past criminality motivate conventional autobiographies of exemplary self-improvement. Malcolm X's 1965 autobiography recounts his youth as a street hustler but also reflects his disaffection with Black middle-class respectability. While Malcolm X's narrative of Black re-formation, self-discipline, and patriarchal masculinity might echo the precedents of uplift autobiography, it insistently derides the Black middle class as deluded and hypocritical, thereby expressing "the latent class anger that lies muffled beneath a racial blanket" (Kelley 1998, 432).

To be sure, this profusion of crime tales likely registered developments in the U.S. after World War II that were extrinsic to the trajectories of Black autobiography, including a growing liberal discourse that redefined criminality in structural (rather than morally absolute) terms, as well as intense sociological concern with the "second ghetto" of high-rise housing projects that concentrated poor and working-class Black people, many fresh from the South, in the deindustrialized inner cities of the North (see Rotella 1998; Hirsch 1998). In this context, the mere appearance of new figures of crime in the 1950s is insufficient for drawing larger conclusions about the trajectories of Black autobiography, since, one could argue, 
they simply appeared in larger numbers to meet market demand for first-hand accounts illuminating the experiences and effects of the urban crisis. Still, Black narratives of criminal self-disclosure were not simply reflections of their time, pandering to the tawdry voyeurism of white Americans. Rather, autobiographers like Malcolm X and Claude Brown were actively engaged in a discursive conflict over the disciplinary politics of racial representation that had failed to serve the needs of a broader Black community. Even more popular upon its publication than The Autobiography of Malcolm X (Rotella 209-10), Brown's Manchild in the Promised Land also represents the critical dimensions of such crime tales.

Beyond Brown's accounts of sexual conquests, Manchild chronicles a youth spent stealing, fighting, and hustling (as well as his own participation in the gang rape of a white sex worker); only occasionally are these activities interrupted by Brown's stints in detention centers and reform schools (Brown 110). As the heroin epidemic of the 1950s transforms the culture and codes of New York's streets, a restless Brown flees Harlem. He eventually moves downtown to the Village and finishes school, thereby eluding the perils engulfing so many of his friends. Still, Brown does not simply replicate a rags-to-respectability narrative, a story of Black success effected by his escape from the ghetto, and even at the end of Manchild, he values his street education over the school education that might offer him some claim on middle-class propriety. While Brown's profane braggadocio, both criminal and sexual, obviously contravenes the politics of respectability, his extensive self-revelation directly challenges the uplift conventions of Black autobiography in two other ways. First, Brown repudiates the form of the conversion narrative that necessarily elevates the present self over the prior self, as when he dismisses former friends who have become Black Muslims or Coptic neophytes in Harlem, saying to himself, "Oh, Lord, here comes some more of that shit about 'how I was saved"' $(225,226)$. Instead, Brown revels in the criminality of his youth, which represents the vitality of Harlem before its devastation by the "shit plague" of heroin (185). Throughout Brown's narrative, this criminal past remains fundamental to his self-consciousness, and even as he moves away from this past, he is unwilling, finally, to renounce it.

Second, Brown outwardly forsakes the disciplinary function of the reformed Black self that had been central to the project of uplift autobiography. He concludes Manchild with a narrative return to Harlem, staged as the prodigal's homecoming, when he encounters his old friend Reno, a hustler who, he writes, "resented me for not resigning myself to a life of petty crime" (410). Once Brown mentions his plans to finish school, Reno cautions him, "Now, baby, don't go down there and come back the Man. That'd be some real wicked shit. All the stuff we been through together, if you became the Man and busted me or any of the cats around the neighborhood, that shit would really hurt, man" (410). After Brown reassures him, Reno adds, "I may need you for somethin' one day. You go down there and you become a big-time lawyer, big-time doctor, big-time teacher, big-time anything. Just don't become a big-time preacher...I just can't use you if you go do somethin' like that" (411). With this brief exchange, Brown's 
narrative stresses the obligations of Black teachers, preachers, and professionals: rather than stand as distant emblems of Black propriety, they should bridge the distance between themselves and the Black working class, making themselves useful according to the needs of the people. Most importantly, Brown reasserts his loyalty to Harlem's thieves, an allegiance that rejects the disciplinary function of racial publicity. Rather than return to his past to police the thieves-or silence the disreputable figures that had always haunted uplift autobiography-Brown embraces his duty to the streets as a Black man who refuses to become the Man.

\section{From Respectability to Authenticity}

The forms of sexual and criminal self-disclosure that emerge in Black male autobiography result in part from cultural dynamics originating beyond the Black public sphere, but they are not merely the epiphenomena of larger social forces. Nor are they merely an adaptation of the cultural politics of racial synecdoche, as though autobiographers like Claude Brown, Malcolm X, Horace Cayton, and Saunders Redding simply substitute a much more revelatory-and, perhaps, disreputable-Black narrator to stand for the racial collective. Refracting the residual conventions of racial uplift ideologies, these narrators directly bind such self-disclosure to critiques of Black middle-class figures and the disciplinary constraints of racial publicity. Autobiographies involving the criminal and sexual disclosure of Black men thus directly confronted the longstanding imperatives of Black autobiographical production, challenging the accredited ideal that mystified the interests of a discrete class of Black elites while centering an "authentic" mass that had been silenced by the politics of racial image. Earlier Jim Crowera autobiographers had relied upon demonstrations of status, responsibility, and respectability to authorize their synecdochic value, even as these qualifications italicized the distance between them and the Black masses; their duty to Black people did not necessarily mean that they were (still) of the people. In contrast, their eventual challengers relied upon assertions of racial authenticity that valued closeness rather than distance, and they contested the lingering forms of Black autobiographical production driven by the logic of middle-class formation.

I must conclude with a caution, however. I am not arguing reductively that we should map a narrative of progress onto the history of Black autobiographical production, as if twentieth-century Black autobiography simply evolved from the repressive constraints of bourgeois conservatism, as if the uplift narratives of the early Jim Crow era simply reflected the disciplinary demands of burdened individuality while the later narratives of criminal and sexual self-disclosure instantiated the Black subject liberated from such discipline-as if, in short, Black autobiography simply became increasingly authentic as the twentieth century unfolded. Instead, my concern here is with the emergence of "authentic" Blackness as a discursive production, a historically contingent maneuver in an intraracial class conflict over cultural forms of Black representation. Moreover, the gendering of racial authenticity according to the phallocentric masculinity of 
some Black male autobiographers erected its own exclusive boundaries around the racial collective that perpetuated male domination, especially under the sign of Black nationalism. The contending discourses of Black autobiography, then, were the discourses of respectability and authenticity; in the wake of the 1960s, the gendered dictates of racial authenticity, slowly overshadowing the pressures of respectability, would become a briar patch confronted by nearly all Black autobiographers in the post-Civil Rights era.

\section{Notes}

1. For my purposes, the slave narrative refers to a firsthand account published in book or some other discrete form, a subset of the larger category of slave narration, which encompasses testimonies transcribed in newspapers or otherwise interpolated into other texts, firsthand accounts of slavery delivered on the abolitionist lecture circuit, etc. Likewise, Black autobiography refers to discrete texts, a subset of the more capacious category of Black autobiographical practices.

2. Other postbellum slave narratives published after 1901 include books by Morgan Latta (1903), Nat Love (1907), Thomas W. Burton (1910), William Robinson (1913), Isaac Lane (1916), Alexander Walters (1917), Jared Arter (1922), William H. Heard (1924), Peter Bruner (1925), Emma Ray (1926), Robert Anderson (1927), and Sam Aleckson (1929).

3. While focusing on urban, working-class women rather than the "folk," Carby's influential article, "Policing the Black Woman's Body in an Urban Context," analyzes how representations of Black women's sexuality staged intraracial class conflict during the Great Migration.

\section{References}

Allyn, David. Make Love, Not War: The Sexual Revolution, an Unfettered History. Little, Brown, 2000.

Andrews, William L. "Forgotten Voices." a/b:Auto/Biography Studies, vol. 2, 1986, pp. $21-31$.

Andrews, William L. "The Representation of Slavery and the Rise of Afro-American Literary Realism, 1865-1920." Slavery and the Literary Imagination, edited by Deborah E. McDowell and Arnold Rampersad, Johns Hopkins UP, 1989, pp. $62-80$.

Andrews, William L. Slavery and Class in the American South: A Generation of Slave Narrative Testimony, 1840-1865. Oxford UP, 2019.

Bederman, Gail. Manliness \& Civilization: A Cultural History of Gender and Race in the United States, 1880-1917. U of Chicago P, 1995.

Brown, Claude. Manchild in the Promised Land. Macmillan, 1965.

Carby, Hazel V. Race Men. Harvard UP, 1998.

Cayton, Horace. Long Old Road. Trident Press, 1965.

Eagleton, Terry. Ideology: An Introduction. Verso, 1991.

D’Emilio, John, and Estelle B. Freedmen. Intimate Matters: A History of Sexuality in America. Harper \& Row, 1988.

Ferebee, L. R. A Brief History of the Slave Life of Rev. L. R. Ferebee, and the Battles of Life, and Four Years of His Ministerial Life. Edwards, Broughton \& Co., 1882. 
Franklin, H. Bruce. Prison Literature in America: The Victim as Criminal and Artist. Expanded ed., Oxford UP, 1989.

Gaines, Kevin K. Uplifting the Race: Black Leadership, Politics, and Culture in the Twentieth Century. U of North Carolina P, 1996.

Gaines, Thomas S. Buried Alive (Behind Prison Walls) for a Quarter of a Century: Life of William Walker. Friedman \& Hynan, 1892.

Gates, Henry Louis, Jr. “Writing, 'Race,' and the Difference It Makes." Loose Canons: Notes on the Culture Wars, Oxford UP, 1992, pp. 43-69.

Gilmore, Al-Tony. Bad Nigger!: The National Impact of Jack Johnson. Kennikat Press, 1975.

Grieveson, Lee. Policing Cinema: Movies and Censorship in Early-Twentieth-Century America. U of California P, 2004.

Hartman, Saidiya V. Scenes of Subjection: Terror, Slavery, and Self-Making in Nineteenth-Century America. Oxford UP, 1997.

Herndon, Angelo. Let Me Live. 1937. U of Michigan P, 2007.

Hirsch, Arnold R. Making the Second Ghetto: Race and Housing in Chicago, 19401960. 2nd ed., U of Chicago P, 1998.

Hooks, Bell. "Reconstructing Black Masculinity." Black Looks: Race and Representation, South End Press, 1992, pp. 87-113.

Hughes, Louis. Thirty Years a Slave. 1897. Mnemosyne, 1969.

Johnson, Jack. Jack Johnson-In the Ring-and Out. 1927. Citadel Press, 1992.

Jones, Thomas Alfred. The Secret. Comet Press Books, 1958.

Kelley, Robin D. G. "House Negroes on the Loose." Callaloo vol. 21, no. 2, 1998, pp. 419-35.

Lamont, Hammond. Negro Self-Help. Tuskegee Institute Press, [1904].

Lewis, J. Vance. Out of the Ditch: A True Story of an Ex-Slave. Rein \& Sons, 1910.

Marable, Manning. Malcolm X: A Life of Reinvention. Penguin, 2011.

Medovoi, Leerom. "A Yippie-Panther Pipe Dream: Rethinking Sex, Race, and the Sexual Revolution." Swinging Single: Representing Sexuality in the 1960s, edited by Hilary Radner and Moya Luckett, U of Minnesota P, 1999, pp. 133-78.

Miller, Kelly. "Eminent Negroes." 1908. Radicals and Conservatives: And Other Essays on the Negro in America, Schocken, 1968, pp. 200-12.

Mingus, Charles. Beneath the Underdog: His World as Composed by Mingus. Knopf, 1971.

Mitchell, Michele. Righteous Propagation: African Americans and the Politics of Racial Destiny after Reconstruction. U of North Carolina P, 2004.

Moore, Archie Lee. The Archie Moore Story. McGraw-Hill, 1960.

Moses, Wilson Jeremiah. "Sexual Anxieties of the Black Bourgeoisie in Victorian America: The Cultural Context of W. E. B. Du Bois's First Novel." The Wings of Ethiopia: Studies in African-American Life and Letters, Iowa State UP, 1990, pp. 247-63.

Muhammad, Khalil Gibran. The Condemnation of Blackness: Race, Crime, and the Making of Modern Urban America. Harvard UP, 2010.

Murray, Rolland. Our Living Manhood: Literature, Black Power, and Masculine Ideology. U of Pennsylvania P, 2007. 
Nash, Ide D. Bootlegging a Failure and a Lecture to Young Men: My Prison Experiences in Oklahoma. [Author], 1918.

Patterson, Floyd, and Milton Gross. Victory Over Myself. Bernard Geis Associates, 1962.

Patterson, Haywood, and Earl Conrad. Scottsboro Boy. Doubleday, 1950.

Redding, J. Saunders. No Day of Triumph. Harper and Bros., 1942.

Roberts, Randy. Papa Jack: Jack Johnson and the Era of White Hopes. Free Press, 1983.

Rotella, Carlo. October Cities: The Redevelopment of Urban Literature. U of California P, 1998.

Runstedtler, Theresa. Jack Johnson, Rebel Sojourner: Boxing in the Shadow of the Global Color Line. U of California P, 2012.

Rustin-Paschal, Nichole. The Kind of Man I Am: Jazzmasculinity and the World of Charles Mingus Jr. Wesleyan UP, 2017.

Slim, Iceberg. The Naked Soul of Iceberg Slim. Holloway House, 1971.

Slim, Iceberg. Pimp: The Story of My Life. Holloway House, 1967.

Tate, Claudia. Domestic Allegories of Political Desire: The Black Heroine's Text at the Turn of the Century. Oxford UP, 1992.

Thomas, Matt. Hopping on the Border: The Life Story of a Bellboy. The Naylor Company, 1951.

Ward, Geoffrey C. Unforgivable Blackness: The Rise and Fall of Jack Johnson. Random House, 2004.

Washington, Booker T. Up from Slavery. 1901. W. W. Norton, 1996.

X, Malcolm, and Alex Haley. Autobiography of Malcolm X. 1965. Ballantine, 1973.

Recebido em: 01/12/2020

Aceito em:16/03/2021 